Bu makaleye atıfta bulunmak için/To cite this article:

ARTYSHEVA, M. YURDİGÜL, A. (2021). Role Perceptions of Public Relations Practitioners: Kyrgyzstan Sample. Atatürk Üniversitesi Sosyal Bilimler Enstitüsü Dergisi, 25 (4), 1573-1592.

\title{
Role Perceptions of Public Relations Practitioners: Kyrgyzstan Sample
}

\author{
Meerim ARTYSHEVA ${ }^{*}$ \\ Asll YURDIGGÜL ${ }^{(* *)}$
}

\begin{abstract}
In order to determine the condition of the public relations sector in a particular country, it is important to define the role perception public relations practitioner. Studies aimed at roles in public relations started in 1978, when the first research was conducted by Broom and Smith. As a result of this study, 5 fundamental roles of practitioners were identified. In Kyrgyzstan, public relations field began to develop after the 90 s with the acquisition of independence.. This study presents the results of a research aimed at identifying the fundamental roles of public relations practitioners in Kyrgyzstan. This study based on the work of Broom and Smith. In-depth interviews were conducted with 24 public relations practitioners to determine which basic roles they fulfilled. As a result of the research, it has been revealed that the public relations practitioners in Kyrgyzstan play 4 roles among 5 basic roles and more technician roles than the manager role categories.
\end{abstract}

Keywords: Public relations, public relations roles, role perceptions, public relations role practitioners, Kyrgyzstan.

\section{Halkla İlişkiler Uygulayıcılarının Rol Algılamaları: Kırgızistan Örneği}

Öz: Belirli bir ülkede halkla ilişkiler sektörünün durumunu tespit etmek için halkla ilișkiler uygulayıcılarının rol algılamalarını tanımlamak önemlidir. Halkla ilişkilerde rollere yönelik çalıșmalar 1978 yılında Broom ve Smith 'in ilk araștırmasıyla bașlamıștır. Kırgızistan'da, halkla ilişkiler alanı 90'lardan sonra bağımsızlı̆̆ın kazanılmasıyla gelişmeye başlamıştır. Bu çalışma, Kırgızistan'daki halkla ilişkiler uygulayıcılarının temel rol algılamaların belirlemeyi amaçlayan araştırmanın sonuçlarını sunmaktadır. Çalışma Broom ve Smith'in belirlediği 5 temel role dayanmaktadır. Bu kapsamda 24 halkla ilişkiler uygulayıcısı ile derinlemesine görüşmeler yapılmıştır. Araştırma sonucunda, Kırgızistan'daki halkla ilişsiler uygulayıcılarının 5 temel rol arasında 4 rolü yerine getirdiği ve yönetici rol kategorilerine göre daha fazla teknisyen rolü benimsedikleri ortaya çıkmıştır. Çalışma Kırgızistan'da halkla ilişkiler uygulayıcılarının rol algılaması üzerine yapılan ilk araştırma olduğu için büyük önem taşımaktadır.

Anahtar Kelimeler: Halkla ilişkiler, halkla ilişkilerde roller, rol algılamaları, halkla ilişkiler uygulayıcıları, Kırgızistan.

Makale Gelis Tarihi: 11.06.2021

Makale Kabul Tarihi: 21.12.2021

DOI: 10.53487/ataunisosbil.951280

\footnotetext{
*) Öğr. Gör. Dr., Kırgızistan-Türkiye Manas Üniversitesi İletişim Fakültesi Halkla İlişkiler ve Reklamcılık Bölümü (e-posta: meerim.artiseva@manas.edu.kg) (DD ORCID ID. https://orcid.org/ 0000-0002-5400-2410

$\left.{ }^{* *}\right)$ Prof. Dr., Atatürk Üniversitesi İletişim Fakültesi Radyo Televizyon ve Sinema Bölümü (eposta: asli.yurdagul@hotmail.com) (D) ORCID ID. https://orcid.org/0000-0001-5333-9751

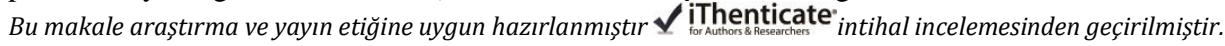




\section{Introduction}

In this study, professional role perceptions of public relations practitioners in Kyrgyzstan, one of the Central Asian countries, were investigated. This study is the first research on the professional role perceptions of public relations practitioners in Central Asian countries, especially in Kyrgyzstan. In the same period, the public relations field in Central Asian countries (Kyrgyzstan, Kazakhstan, Uzbekistan, etc.) emerged after the USSR collapsed and Central Asian countries gained independence and it started to improve in the following periods.

Professional and occupational education has been provided in the region since the early 2000s. Due to these reasons, academic studies on this field could not be carried out sufficiently and no infrastructure could be established. Given this information, this study on the professional role perceptions of public relations practitioners in Kyrgyzstan is of vital importance for both Kyrgyzstan and Central Asian countries. For this reason, Broom and Smith's role categories which cover the basic roles of public relations practitioners have been addressed in this study.

The development of public relations in Kyrgyzstan differs from the development models of America or European countries. Public relations in Kyrgyzstan, especially in recent years, is a developing field. However, the emergence and use of the public relations concept go back to the first years of the independence period. The country's political, economic and cultural structure was restructured in 1991 when the country gained its independence. With this restructuring, the country has started to take part in international organizations; and signed agreements for economic, cultural and political cooperation with many countries. In this process, especially after 1999, with the support of America and European countries, many non-governmental organizations have been established in the country and they started to operate in various fields. These activities have been carried out as free consultancy, seminars and forums in such areas as democratization, human rights, gender, education, etc. towards which people are much more sensitive. Some non-governmental organizations have run social projects on social problems together with local administrations (Shulte, 2008: 5 - 6). The first foundations of public relations in the country have been laid through these practices carried out by different institutions and individuals.

Public relations was first implemented in the country within the scope of political communication studies. Together with the parliamentary system that started after the independence, the candidates have needed public relations activities to promote themselves and their parties. Through these activities carried out during the election periods, the country learned public relations, even though it could not name it professionally.

The next development period of public relations in Kyrgyzstan is constituted by studies conducted by the international private companies operating in the country. These institutions in question resorted to public relations practices in order to introduce themselves and to create a positive public opinion. Among these practices carried out by international companies, especially crisis management has an important place. The 
accident occurred in the Issik Lake region of the country in 1998 can be given as an example. In this accident, a cyanide-laden vehicle of "Kumtor Operating Company" which operated in the field of gold mining had an accident and cyanide poured into the Barskoon river, which flows into Issık Lake. As a result of the accident, many people using the water of the river were poisoned and tourists stopped going to the Issık Lake, which is the most touristy region of the country. The company then ran an intensive public relations campaign for the region; and put many financial and moral projects into practice to win the local people round. The company paid compensation to the victims of the accident and the employment policy of the company was rearranged in favour of local people. Accordingly, the company imposed the obligation that $90 \%$ of the people to be employed should be from the Issyk Lake region.

As the importance of public relations started to be understood in the country, the first step towards professionalization was the beginning of vocational training. The first public relations education in Kyrgyzstan, started to be given in 2000 in the Public Relations and Advertising Department opened within the body of the Communication Faculty of Kyrgyzstan-Turkey Manas University. This was followed in 2003 by the public relations lessons given in the Department of Political Science, Advertising and Public Relations in the Institute of Social Sciences in İ. Arabayev Kyrgyz State University, and in 2004 by the public relations lessons in the Department of Journalism in Balasagun Kyrgyz National University and K. Karasayev Bishkek Social Sciences University. In 2006, public relations and advertising classes started in Business Administration Department of Kyrgyz State Construction University of Transportation and Architecture, and in 2013 in the Faculty of Literature in B. Yeltsin Kyrgyz-Russian Slavyan University. The education has been determined to last for 4 years; and the eductional standards of the department have been determined by Kyrgyz Republic Ministry of Science and Education, and general field courses, specialization courses include internship programs and state examinations (Artışeva, 2017: 548).

The interest in the public relations profession in Kyrgyzstan is increasing day by day and more people turn towards this area. According to the K. News agency 'public relations and advertising " is in the 5th rank among the TOP-10 professions preferred by students in Higher Education Institutions of Kyrgyzstan. By grasping the importance of public relations, national and international private institutions need more public relations employees than before and allocate specific budgets for the activities in this field (Vzglyad, 2014). However, the development of the field in public institutions has been slower. Public relations activities in these institutions have been carried out in the press agency model for many years.

In Kyrgyzstan, considering both the development of the public relations and the conditions of the country, practitioners working in this field should have a different set of characteristics compared to other countries. First and foremost, practitioners have to take into account the current conditions and act accordingly. They should also address facts and cases from a strategic point of view considering social reality. They should be able to use the principles of public relations such as business, marketing, advertising and event organization successfully. Considering such reasons, it is seen that public relations 
practitioners in Kyrgyzstan are working in different positions and titles, and they take professional roles not only in the field of public relations but also in different professional fields. However, it is not possible to make definitions or to draw the lines of these roles in daily working life. For this reason, public relations practitioners in the country perform different professional roles from each other and other countries depending on their institution, position, or title.

\section{Literature Review}

The first academic study to determine the professional roles of public relations practitioners was carried out by Broom and Smith (1978). As a result of this study, the basic professional roles of public relations practitioners are divided into 5 categories. These roles have been named as expert prescriber, communication process facilitator, problem solver, technical services provider and acceptant-legitimizer. This study of Broom and Smith has been the basis for the research on the roles of public relations practitioners in the coming years. Further Broom (1986) adapted these roles to organizational systems. However, with the development of the field of public relations, the professional roles of public relations practitioners have expanded and the role research on this subject has increasingly continued. In this process, some role research has come to the fore more than others; and they have constituted the main basis of the literature. In 1983, it was determined whether the members of the Public Relations Department of the Journalism and Mass Communication Association perceive public relations practitioner roles. As a result of the research, the members of the association stated that the role of communication technician differed from the other 4 roles because it includes the function of preparing news and messages. Dozier (1984) identified the professional roles of public relations specialists under two main categories: technician and managerial roles. Toth, Serini, Whright and Emig (1998) applied Dozier's technician and managerial roles to the members of the American Public Relations Association. Johnson (1997) identified how business technologies affect public relations practitioner roles among members of the American Public Relations Association (PRSA). As a result, it has been determined that by using technologies, the practitioners can develop two-way symmetric communication in their institution and that the practitioners can transition from the role of public relations technician to public relations manager. In the study conducted by Berkowitz and Hristodoulakis (1999) the relationship between socialization and public relations education in the workplaces was examined based on the literature on the roles of public relations practitioners. Moss (2000) examined public relations practitioners roles at senior management level. In 2001 Vercic, Van Ruler, Bütschi and Flodin (2001), put forth four public relations practitioner roles - operational role, reflective role, executive role and educational role in their study conducted to determine the role of public relations practitioners in Europe. As a result of the professional role research conducted by Petersen, Holtzhausen and Tindall (2002) in South Africa, the contact authority, media relations, cultural commentator and personal impact creater roles were identified in the public relations profession. These roles show that public relations experts in Africa have developed their own unique role models apart from the American and European public relations models (Steyn, 2009). 


\section{Methodology}

\section{A. The Research Universe and Sample}

Public relations specialists and practitioners working in the public relations field in Kyrgyzstan are the population of this study. These practitioners are the persons who perform public relations practices in private and public institutions; in non-governmental organizations; advertising, public relations, marketing and consulting agencies. Although their titles and positions are different, they perform public relations practices by their professional roles.

When the public relations activities in Kyrgyzstan are examined, it is seen that these activities are conducted under the name of public relations departments in large scale enterprises. However, the situation in medium-sized enterprises is much different. In these enterprises, it is observed that public relations is not positioned as a separate department; and that mostly marketing, advertising and public relations activities are carried out at the same time. Public relations practices in public enterprises are carried out by press secretaries. Specialists who perform public relations practices in different institutions and enterprises in the country; have such titles as public relations specialist, marketing and sales specialist, media relations specialist, foreign relations specialist, press secretary, public relations manager, communications specialist. In large scale enterprises, each specialist working in the public relations departments carries out a tight and specific set of tasks. However, in small and medium sized enterprises, one specialist carries out both public relations and other (marketing, advertising, media relations) practices together.

The research sample was established by considering the current situation of public relations practitioners in the country. In this context, 24 public relations practitioners working in national and international institutions were included in the sample. In the study where purposeful sampling was used as sampling method, such online professional guides as www.2gis.kg, www.inform.kg, www.yellowpages.akipress.org were consulted in order to create the sample (since there is no database in Kyrgyzstan to gather information about public relations practitioners in Kyrgyzstan). The identified companies were reached through these guides and it was determined whether they have public relations departments or employees who conduct public relations activities. If so, it was determined if they would participate in the interview.

It has been seen that many of the public relations practitioners constituting the sample carry out public relations activities as a department or alone. This difference is reflected into the positions of practitioners within the institution. Participants perform public relations activities under the titles of public relations specialist, marketing and sales specialist, media relations specialist, foreign relations specialist, press secretary, public relations manager and communications specialist.

\section{B. Data Collection Tool}

In this study, 'in-depth interview' technique was used as data collection technique. Interview is applied to reveal people's perspectives, experiences, feelings and perceptions (Karataş, 2015: 64). The questions were prepared in two categories related 
to the socio-demographic characteristics and professional roles of the participants. The questions prepared to get information about socio-demographic characteristics were prepared as closed questions; while the questions on role perceptions were left openended for the participants to express their feelings and thoughts more freely and comfortably. Through these questions, performance-oriented information has been gathered in almost all areas related to the demographic characteristics of public relations practitioners, their position in the organization, the basic professional roles they undertake and the categories and executive functions of these roles. During the interview, participants were allowed to intervene in the interview and, flexibility and standards were used together in new questions and topics

\section{Data Analysis}

Descriptive analysis of research data has been done. In the description process, expressions are taken directly from the statements of the participants, and they are explained as intention, context and processes (Dey, 1993). Then, based on these expressions, cause-effect relationships are established between the data; prospective inferences are made by making some interpretations (Şimşek and Yıldırım, 2005: 221). The model of the study is consisted of the professional role research of Broom and Smith (1978), which is the first study on the roles of public relations practitioners. In this study, Broom and Smith have identified 5 basic role categories taking into account the duties and activities of public relations practitioners: expert prescriber, communication process facilitator, problem solver, technical services provider and acceptant-legitimizer. They have also divided these roles into different categories. Accordingly, subcategories of expert prescriber role consist of a total of 8 sub-categories: situation analysis and advice, patient-doctor relationship, problem identification and resolution authority, active, institutional analysis, prevention and control of adverse events, checking conditions and providing alternative solutions.

In total there are 6 sub-categories of the communication process facilitator role: communication service provider, interpreter, and mediator, adviser in corporate communication, corporate agenda determiner, response and feedback revealer, bilateral information flow provider, and representative of mutual interests. Subcategories of technical services provider role have been identified as; preparation of brochuresbooklets, preparation of photographic and graphic materials, text authorship, text editor, events organizer, preparation of radio-tv products, organizing press conference. The subcategories of the problem solver role are; identifying problems and explaining them to others, planning and presenting action options, helping management in time of crisis, trying to change inappropriate policies. The sub-categories of the acceptant-legitimizer role are divided into 3 subcategories as; psychological consultation, empathy support and listening and legitimizing corporate and executive decisions, representing corporate interests.

\section{IV.Findings}

The findings obtained at the end of the study were grouped as 'the findings related to the socio-demographic characteristics' and 'the findings related to professional role 
perceptions of participants. The data obtained according to their socio-demographic characteristics was gathered under the title of age, gender, education, work experience, field of activity of the institution, department, title/position and membership to professional associations. Findings on their professional role perceptions were evaluated under the role categories of expert prescribers, communication process facilitator, technical service provider, problem solver and acceptant-legitimizer.

\section{A. Findings on Socio-Demographic Characteristics}

The average age of the public relations practitioners who participated in the study is 29. It is seen that the participants are usually between the age of 26-30. The most important reason why participants are within this age group, which is considered as the young category, is that the public relations field is a new and developing field in the country. In terms of gender, $79.2 \%$ is female and $20.8 \%$ is male. In this sense, the public relations profession in Kyrgyzstan is seen to be carried out mostly by women.

Table 1: Age Distribution of Participants

\begin{tabular}{|c|c|r|c|}
\hline Age Category & $\begin{array}{c}\text { The number of } \\
\text { Participants }\end{array}$ & Percent & Current Persentage \\
\hline $20-25$ & 4 & 16,66 & 16,7 \\
\hline $26-30$ & 11 & 45,83 & 45,8 \\
\hline $31-35$ & 6 & 25 & 25 \\
\hline $36-40$ & 3 & 12,5 & 12,5 \\
\hline $41-45$ & 0 & - & - \\
\hline $46-50$ & 0 & - & - \\
\hline Total & 24 & 99.99 & 100 \\
\hline
\end{tabular}

In terms of educational status of participants; $58.3 \%$ has a bachelor's degree and $37.5 \%$ has a master's degree. One participant graduated from the doctoral program. Considering the type of education participants have, it is seen that the graduates of different departments of social sciences can work in this field. As a matter of fact, $37.5 \%$ of the participants graduated from public relations and advertising, $25 \%$ from journalism, $8.3 \%$ from marketing, $12.5 \%$ from law and $4.16 \%$ from business, economics, linguistics and construction. Therefore, people having studied different departments can work as public relations specialist or public relations practitioner in the country. One of the main reasons for this is that public relations are based on creating mutual communication, understanding, respect and trust; on the other hand, it requires management and organization skills and it is considered sufficient when the specialist working in this field get education in the fields of communication, media, business, marketing and advertising. Although education is seen as important criterion the company for professionalization of the job, it should be noted that the vocational education has a short history of 15 years. 
Table 2: Education of Participants

\begin{tabular}{|c|c|r|c|}
\hline The Type of Education & $\begin{array}{c}\text { The number of } \\
\text { Participants }\end{array}$ & Percent & Current Persentage \\
\hline Bachelor & 14 & 58,33 & 58,3 \\
\hline Master & 9 & 37,5 & 37,5 \\
\hline PhD & 1 & 4,16 & 4,2 \\
\hline Total & 24 & 99,99 & 100 \\
\hline
\end{tabular}

Table 3: Department of Graduation of Participants

\begin{tabular}{|c|c|r|c|}
\hline Departments & $\begin{array}{c}\text { The number of } \\
\text { Participants }\end{array}$ & Percent & Current Persentage \\
\hline $\begin{array}{c}\text { Public Relations and } \\
\text { Advertising }\end{array}$ & 9 & 37,5 & 37,5 \\
\hline Journalism & 6 & 25 & 25 \\
\hline Marketing & 2 & 8,33 & 8,3 \\
\hline Management & 1 & 4,16 & 4,2 \\
\hline Law & 3 & 12,5 & 12,5 \\
\hline Economy & 1 & 4,16 & 4,2 \\
\hline Linguistics & 1 & 4,16 & 4,2 \\
\hline Construction & 1 & 4,16 & 4,2 \\
\hline Total & 24 & 99,97 & 100,1 \\
\hline
\end{tabular}

The professional experience of public relations practitioners in Kyrgyzstan generally varies between 4-6 years. Because the emergence of public relations field and its construction in the sense of professionalism is also quite new. In the country especially after 2010, the public relations profession emerged in the sense of professionalism and it started to be accepted as a corporate need. The institutionalization of public relations activities was realized within the public relations, public relations and advertising, marketing, sales, media relations, marketing and public relations departments. Public relations practitioners have mostly taken charge in the advertising, sales or marketing departments in the early periods of the profession. In the following periods, upon understanding the importance of the profession, public relations has started to take place as an institutional unit within the organizational chart. $33.3 \%$ of the specialists who participated in this research work in public relations, $8.3 \%$ works in public relations and advertising, 25\% works in marketing and others, sales, marketing, public relations and media relations departments. In addition, $20.8 \%$ of the participants work as separate specialists in their companies, they do not work in a department. 
Table 4: The Professional Experience of Participants

\begin{tabular}{|l|c|c|c|}
\hline $\begin{array}{c}\text { Professional } \\
\text { Experience }\end{array}$ & $\begin{array}{c}\text { The number } \\
\text { of } \\
\text { Participants }\end{array}$ & Percent & Current Persentage \\
\hline 1-3 years & 3 & 12,5 & 12,5 \\
\hline 4-6 years & 14 & 58,33 & 58,3 \\
\hline 7-9 years & 4 & 16,66 & 16,7 \\
\hline 10-12 years & 2 & 8,33 & 8,3 \\
\hline 13-15 years & - & - & - \\
\hline More than 15 years & 1 & 4,16 & 4,2 \\
\hline Total & 24 & 99,98 & 100 \\
\hline
\end{tabular}

Table 5: Department Where Participants Work

\begin{tabular}{|l|c|r|c|}
\hline \multicolumn{1}{|c|}{ Department } & $\begin{array}{c}\text { The number } \\
\text { of } \\
\text { Participants }\end{array}$ & Percent & Current Persentage \\
\hline Public relations & 8 & 33,33 & 33,3 \\
\hline $\begin{array}{l}\text { Public relations and } \\
\text { advertising }\end{array}$ & 2 & 8,33 & 8,3 \\
\hline Marketing & 6 & 25 & 25 \\
\hline Sales department & 1 & 4,16 & 4,2 \\
\hline $\begin{array}{l}\text { Marketing and public } \\
\text { relations }\end{array}$ & 1 & 4,16 & 4,2 \\
\hline Media relations & 1 & 4,16 & 4,2 \\
\hline $\begin{array}{l}\text { Does not apply to any } \\
\text { department }\end{array}$ & 5 & 20,83 & 20,8 \\
\hline Total & 24 & 99,97 & 100 \\
\hline
\end{tabular}

In Kyrgyzstan, public relations practitioners generally work as a public relations specialist. Furthermore, it is seen that they also work under the titles of public relations manager, marketing specialist and communication specialist. Some of the participants are marketing manager and press secretary. 
Table 6: The Position of Participants

\begin{tabular}{|l|c|r|c|}
\hline \multicolumn{1}{|c|}{$\begin{array}{c}\text { The Position of } \\
\text { Participants }\end{array}$} & $\begin{array}{c}\text { The number } \\
\text { of } \\
\text { Participants }\end{array}$ & Percent & Current Persentage \\
\hline Public relations manager & 5 & 20,83 & 20,8 \\
\hline Public relations specialist & 11 & 45,83 & 45,8 \\
\hline Marketing manager & 1 & 4,16 & 4,2 \\
\hline Marketing specialist & 3 & 12,5 & 12,5 \\
\hline Press secretary & 1 & 4,16 & 4,2 \\
\hline $\begin{array}{l}\text { Communication } \\
\text { specialist }\end{array}$ & 3 & 12,5 & 12,5 \\
\hline Total & 24 & 99,98 & 100 \\
\hline
\end{tabular}

Public relations practitioners in Kyrgyzstan have not been organized professionally. The main reason for this is that the field has just begun to develop recently, sector specialists and academicians do not come together very often and that academic studies in the field are not done sufficiently. Therefore, none of the participants are members of any professional public relations organization. In particular, the lack of a national levelprofessional public relations association in the country poses problems for the legal and ethical adjustment of the profession. The fact that people cannot be members of international professional associations due to language, culture and so on... causes practitioners not to know basic professional principles and not to follow the latest developments and tendencies in the field.

\section{B. Findings on Professional Role Perceptions}

Expert Prescriber Role: $52.71 \%$ of the participants have the characteristics of the expert prescriber role. Participants with these characteristics analyze the situation when a problem arises and review internal and external factors. For problems other than their field of activity, they seek advice of the experts of that field. They produce solution proposals for the problems and they offer these proposals to the management. The roles of practitioners who have taken this role are compared to the patient-doctor relationship. The important point in this role is that practitioners are effective in the process of offering solutions rather than solving problems. One of the participants who have taken this role expressed his/her professional role and responsibilities with the following words;

Participant:“...I determine separate solutions for each situation by developing communication programs. I produce template-draft solutions for every situation, and I also add my views as what we should add to make it better; I share my thoughts as "it would be better if we do this, we need to explain this information". I am responsible for all the papers and texts prepared on behalf of the institution. In addition to texts, I give my own advice on what to do in other communicative issues. However, if the problems are serious, I absolutely keep the law department in loop and offer solutions and suggestions." 
Practitioners who play the role of expert prescriber do not take part in the implementation of communication and public relations programs. They serve as a source of information and they mostly answer questions. This situation is seen in research findings as 'participants inform the authorities about the situation and offer suggestions on what to do instead of putting the problem- solving suggestions into practice'.

Practitioners who play the role of expert prescriber should have some supervisory and preventive recommendations against potential situations, although they do not directly interfere with the problems. It has been seen that the participants of the study have solution proposals for the potential problems. However, these proposals are prepared based on the past experiences of practitioners; therefore, they are not sufficient. In this sense, it can be said that the practitioners who undertake this role are not in proactive but in a reactive public relations process. Practitioners who undertake this role do not perform a systematic organizational analysis; they intervene in problems once they come out. These practitioners work mainly for customers and the media. In this context, they conduct processes such as the perception of corporate image by the customers, revealing customer preferences and interests, and placing corporate news on media. The participants shared the following information on their duties and responsibilities.

Participant: “... Public relations practitioners should be prepared for unexpected situations. Especially in time of crisis. In such cases firstly, we are trying to collect the correct information. However, we are aware that we need to move very quickly in doing so. We are trying to analyze all unexpected situations immediately and gather the required information. Thus, we are prepared for similar problems to arise in the future..."

Another participant: “...Firstly, we conduct media analysis, we especially review news websites accordingly. In addition, we analyze the complaints and requests received from our call center and we use them as data. We have branches in the regions, the manager of each branch informs us about the situation in the regions. We develop our activity programs in the light of this data..."

It has been seen that public relations practitioners who participated in the research develop solutions to the problems and offer them to the management; but they do not take an active role with this regard. However, the role of the expert prescriber requires the practitioners to act as an authority. Therefore, public relations practitioners in Kyrgyzstan content themselves with providing the necessary information about the problems and offering solutions.

The role of technical services provider: Public relations practitioners have been seen to undertake the role of technical service provider at most among the 5 basic roles $(69,64 \%)$. In this context, practitioners prepare press releases, write texts and edit texts written by others. Public relations practitioners also prepare brochures, booklets and other graphical materials, or they check the products prepared by the designer: 
Participant:"...I write all the newsletters by myself, we offer them ready to journalists, because I know the goals and missions of the organization well, journalists can not write as we want..."

Participant: “... I have to write one newsletter every day. I'm sending the newsletters to all news agencies. In addition, I prepare articles and interview texts and send them to newspapers. I am also preparing texts for television programs..."

Participant: “...journalists do not write news texts by themselves, they publish the press releases we give, as is. Therefore, it is important that the correct information is given in the newsletter. I am responsible for this..."

Participant: “...We continuously send newsletters to journalists. But in time of crisis, we are talking privately with some important journalists..."

In addition, the participants also organize in-house and external activities. They organize corporate holidays, meetings, seminars and courses as in-house activities. They organize press conferences, workshops for journalists and social responsibility projects for the external environment of the institution. However, it is seen that most participants do not produce video products by themselves; they get external agencies to prepare them. Moreover, they have an active role in the selection of the images to be included in the video:

Participant: “...I organize events for important days, holidays or for introducing a new product. We plan the event from the beginning to the end: the event schedule, presenters, determining the person to speak from the management, the words of the speakers, the list of the participants, determining the invitees from the media..."

Participant: “...I prepare a separate plan for each event. We plan everything in advance including the date, place and time of the event, partners to be invited, the way how we will reflect the event into the media, and so on..."

It has been seen that participants are actively involved in the preparation of brochures, posters and corporate publications that require graphic-design; and they lead the person concerned about the preparation of the texts, the selection of the images and the work to be done. It is also their responsibility to issue in-house periodicals. However, some of the practitioners have put forward that brochures, booklets and corporate magazines are getting old; instead, they suggest that publications should be prepared for digital media and internet technologies. Most of the participants, who take the technical service provider role, prepare news texts for the media and journalists; and they also prepare messages and executive speeches to take place in social networks.

The role of communication process facilitator: Public relations practitioners who adopt the role of communication process facilitator manage the communication process for the internal and external target group of the institution. In this context, they are in contact with partners and employees within the company; and with their customers, media, competitors, government, finance sector outside of the company. In the research, it has been seen that the role of communication process facilitator was taken on at the same rate with the role of expert prescriber. $65,27 \%$ of the participants fulfill the role of 
communication process facilitator and provide information exchange between the company and its partners and they also take responsibility for the realization of mutual communication. They conduct communication activities not only for the external target group but also for the organization.

In this context, setting the agenda within the company is one of the basic responsibilities of public relations practitioners who take this role. Apart from this, they also carry out activities related to the communication process such as providing communication between the departments, coordination between the managers, checking the official correspondence, preparing the texts for managers' speeches.

The most important responsibility of the public relations practitioners who take on this role is being an official information source. All kinds of communication activities outside of the organization are their responsibility. In this sense, the corporate image is the result of the activities of the public relations practitioners who play this role. Especially all information for the press is created by practitioners or under their supervision:

Participant: “...Our department has a special place in our institution. Because, other departments' employees ask for our help to communicate with the external environment of the institution through us. In-house and external official letters, correspondence, commercial presentations and application texts are prepared by our department..."

Participant: “...corporate news: important decisions, innovations, celebrations, advertisements are firstly distributed among the employees of the institution with internal communications channels..."

Participant: “...Before conveying information to outside, I coordinate all information with company's departments, especially with sales and marketing department, technical department, and the top management. I'm editing and conveying the messages to be forwarded after receiving their feedback and information..."

Public relations practitioners who act as communication process facilitators work as communication providers, interpreters and mediators between the institution and its external target group. Practitioners provide external target group with opportunities to get answer to their questions, they follow the behavior of the external environment and try to solve the problems of the target customers. Thus, practitioners run the bilateral communication process:

Participant: “...our customers can send their opinions, complaints, presentations and comments to our web-pages, electronic e-mail address and to our pages on social networks. All incoming messages are reviewed and answered. This ensures bilateral communication. In addition, we have a call center in our organization. I teach our call center employees how to talk to the customer. The rules on how to talk and respond are developed for the call center by us..."

Participant: “...we are trying to ensure the bilateral communication process of the institution with its external environment. All messages to be sent are discussed with upper management and the relevant departments in the first stage. After the messages 
are approved, they are distributed by means of communication tools. After that, we examine the reactions to our messages. These reactions can come from our customers, partners or the media. We try to respond to the reactions as soon as possible..."

Participant: “... We are currently trying to conduct an interactive communication with our target customers. In this context, we absolutely use the new media. Our target group conveys their comments. Sometimes we hold focus meetings before taking new decisions. Feedback is very important to us..."

As the social networks become widespread, masses have become more sensitive to institutions. Therefore, institutions also carry out public relations activities in social networks. Moreover, social networks enable institutions to contact their target customers more quickly. Most institutions add an "online consultant" service to their web-pages, enabling customers to get immediate answers to their questions. In this way, institutions can communicate with their target groups, on the one hand they solve the problems that may have a negative impact on their image.

Problem solver role: In the study, it has been seen that $55.2 \%$ of the practitioners fulfill the problem solver role. Participants who adopt this role identify problems in time of crisis and explain them to employees and managers of the institution. The way how this role handles problems poles apart the role of expert prescriber. For example, in the role of expert prescriber, practitioners are considered to be an authority against problems, while they are more passive in this role. Practitioners who take this role content themselves with offering solutions to problems and leave the decision for taking action to the upper management. In this role, practitioners are not decision makers but public relations practitioners who implement the decisions made.

Participant: “... we come up with solutions when problems arise according to the severity of the problem. If the problem is very serious, we inform the top management. However, the top management is constantly following the institution through the social media. Managers are aware of comments, news and reactions in the social media. I produce my own solutions to the problems within my authority. But if the problems are big, the management makes decisions to solve them.

Participant: “... I can solve small problems in my own field. However, the general crisis management program is developed by top management..."

It has been observed that the practitioners participating in the study have mostly identified communication problems and conveyed information to other departments, employees and management. The participants have stated that they develop solutions to the problems and submit these proposals to the approval of the upper management. However, they have reported that they are mostly unprepared against the problems and that they do not get prepared for potential threats and dangers for the institution in advance. For this reason, these practitioners who adopt a reactive public relations strategy are far away from focusing on the moment and making forecast for the future:

Participant: “... we identify all risks and losses to diagnose the problem whenever a problem arises. We then evaluate all the possibilities we have, in order to resolve the 
problems. We identify our weaknesses and strengths. At this stage, we seek an answer to the question whether our own means are sufficient or whether we should ask for help. We develop an action algorithm by distributing information to other employees of the institution. We submit all information to upper management..."

Participant: “... most external conditions may affect the activities of our institution. For example, crises or changes in the national economy are reflected into us. Therefore, we should always consider these situations. If there are problems that we can prevent in advance, we produce solutions to these problems. I'm writing all the measures we can take beforehand..."

It is seen that in the institutions where this role is adopted more, managers are more active and at the forefront than the public relations practitioners. Even though the practitioners who participated in the research offer suggestions for the crisis, they do not prepare crisis programs professionally and do not participate in the crisis management processes.

Acceptant-legitimizer role: The acceptant-legitimizer role has a more negative meaning than other roles among the 5 basic public relations roles identified by Broom and Smith (1978). For this reason, it is seen that sometimes it is not given place in role studies. Because, public relations practitioners who undertake this role support the decisions of the institutions in every situation and try to legitimize them. For this reason, some factors such as the content, accuracy or benefit of the decisions or processes are ignored and the corporate interests are treasured the most. Therefore, practitioners may sometimes circulate falsified, wrong or misleading information about the organization.

The least undertaken role by the participants in the research has been the acceptantlegitimizer role. Only $27.5 \%$ of the participants have stated that they have undertaken this role. Others have stated that they care about the views of their target customers and they approach all kinds of questions and problems precisely and they try to solve them. They have stated that their communication especially through the social media with target customers is very strong, and they are aware that any wrong or falsified information they will give about the institution will grow in a short time and cause much bigger and more important problems. This leads them to act meticulously in the whole communication process. Most of the participants stated that target customers' satisfaction is a priority in public relations practices; and especially, the practitioners working in the service sector said that they give priority to public relations practices to gain customer loyalty. Especially in time of crisis, they take all measures to prevent any damage to the corporate image before target customers:

Participant: “...we are trying to accept our faults in case of any complaint. We commit to solving the problem. We show that we always care about the person..."

Participant: “...our mission is to satisfy the customer. We develop our public relations strategies accordingly..." 
Participant: "... If the institution is not justified in any negative situation, we accept our own fault and take the necessary steps to solve the problem. But if it is not our fault, we defend our opinions to the end..."

When defining the characteristics of the acceptant-legitimizer role, Broom and Smith emphasize that public relations practitioners who undertake this role should provide institution's executives with the support of psychological consultation, listening and empathy. In this case, public relations practitioners should listen to the opinions of the managers of the institution and show that they accept managers' opinions. However, the practitioners participating in this research do not have the characteristics of psychological consultation, listening and empathy support. Most of the participants advise corporate managers in routine and technical works. The managers of the institution seek advice of public relations practitioners only for public relations practices. Managers do not consider practitioners to provide psychological consultation or empathy.

\section{Summary and Discussion}

5 basic public relations roles developed by Broom and Smith set up a theoretical basis for the role research. For this reason, this role is primarily considered in order to determine the public relations roles in different countries. In this study, the professional roles of Broom and Smith were taken as a basis in order to determine the professional roles of public relations practitioners in Kyrgyzstan.

In the light of the data obtained at the end of the study, it has been seen that the participants have adopted and fulfilled 4 of the 5 basic public relations roles. These are expert prescribers, technical service provider, communication process facilitator and problem solver. The technical service provider role $(69,64 \%)$ has been the most adopted one. Public relations practitioners who perform this role prepare materials for the communication process and ensure that the process runs wholesomely; they don't become managers, guiders or decision makers. For this reason, they are quite passive in taking decisions regarding the institution's present time or future, and in determining their corporate strategies and in time of crisis.

This research has revealed the role perception of public relations practitioners in Kyrgyzstan. It is possible to compare role perceptions of public relations practitioners from Kyrgyzstan, USA, European countries and Turkey based on the survey results. However, some studies on this subject should be mentioned for this. For example, in USA in 1983, a study was conducted on the members of the Public Relations Department of the Association of Journalism and Mass Communication. In this study called Public Relations Practitioner Roles - Their Meanings for Educators the role categories of Broom and Smith (1978) were taken as a basis. In the study, it was tried to determine whether the members of the association perceived public relations practitioners' roles. As a result of the study, it was seen that the practitioners performed all roles in a similar way, except for the technical service provider role which is one of the 4 main roles. The decision-making function has become prominent as a key feature of the roles of expert prescriber, communication facilitator and problem solver. However, it was seen that 
there were differences in perceiving and performing technical service provider role. The main reason for this is that the institutional and personal characteristics are more effective in creating news and message content. In the study, while the problem-solver role is defined as the role category that identifies alternative approaches for the organization, emphasizes the importance of public relations studies, identifies problems and puts forth objectives; the communication process facilitator role has been defined as the role category that provides communication between the public opinion and its customers. The basic condition for undertaking the role of expert prescriber is to have sufficient knowledge and experience in the field of public relations (Culberston, 1985).

Another study conducted by Valerie Terry in the USA on public relations practitioners investigated the relationship between practitioner roles and motivation. This study called Lobbyists and Their Stories: Classic PR Practitioner Role Models as Functions of Burkean Human Motivations was applied on 37 lobbyists. In the study where the participants told their work stories, the fundamental roles of the practitioners were determined by analyzing these stories. At the end of the study, it was seen that the participants perform the 5 basic roles developed by Broom and Smith and also took new roles in creation of public policy and customer trainings. In this sense, they displayed 7 motivations in public relations role performance by adopting both public relations manager and public relations technician roles (Terry, 2009).

The first comprehensive study to determine the roles of public relations practitioners in Europe was conducted by Vercic, Van Ruler, Bütschi and Flodin. In this study called 'On the Definition of Public Relations: A European View', 4key roles of public relations practitioners in Europe have been identified within the scope of the European public relations approach. These roles are administrative, operational, reflective and educational roles. Compared to the basic roles of Broom and Smith, executive role corresponds to the roles of expert prescriber, communication process facilitator and problem-solver roles; the operational role corresponds to the of technical service provider role. In this sense, it is seen that public relations practitioners in European countries fulfill the roles developed by Broom and Smith. However, when we compare these results with the roles of public relations practitioners in Kyrgyzstan, there are some differences. One of the most important differences is related to the place of public relations. Public relations is one of the most important organizational structures in the USA and Europe, where public relations is much more historically rooted and completed their developmental stages. Therefore, it is an important management function. Public relations work as an important managerial function in determining corporate policies, creating communication policies, in social responsibility projects, in crisis management, media planning and in many more processes. However, public relations work just as an interim function in Central Asian countries where public relations are quite new as in Kyrgyzstan, where it has just started to improve professionally and occupationally, and where the importance of the public relations has not been understood yet. For this reason, the practitioners here mostly take technician roles; they do not participate in decision-making processes and they content themselves with submitting some information to the management. 
On the other hand, role perceptions of the public relations practitioners in Kyrgyzstan are similar to the role perceptions of practitioners in Turkey. A study called 'An Applied Study on Roles and Perceptions of Public Relations Roles' was conducted by Akar (2011). Within the scope of this study, a total of 279 public relations practitioners working in institutions in Turkey and public relations agencies were applied a survey. At the end of the study, it was determined that the practitioners fulfill their problem solver role, acceptant-legitimizer, communication process facilitator, expert prescriber and technical service provider.

In all studies conducted on the roles of public relations practitioners, the separation between the roles of technician and manager attracts attention. According to this separation; the practitioners who take executive roles identifies corporate public relations policies and programs, conducts sector and target group analysis, establishes corporate communication budgets, mentors other departments and supervises technical specialists. Public relations practitioners who take the technician role develop technical materials that will enable public relations programs structured by others to be conducted. From this point of view, the roles of expert prescriber, communication process facilitator and problem solver that are among the public relations roles of Broom and Smith are the roles that have the characteristics of public relations manager. The technical service provider role has the characteristics of public relations technician role in terms of content and operation.

Practitioners who take the role of managers are those who feel responsible for the success of public relations programs, who takes active role in planning public relations programs and decision-making process, who are authorized to produce solutions to problems and can implement these solutions. It is possible to say that the public relations practitioners in Kyrgyzstan fulfill the managerial roles considering that public relations practitioners who participated in the study have adopted the roles of expert prescriber, communication process facilitator and problem solver. Nevertheless, the duties and responsibilities they perform within the technical service provider role also overlap with the roles of public relations technician; the ratio of those who fulfill this role corresponds to the most fulfilled role, which is $69,64 \%$. This is related to the fact that public relations field in the country is a developing field. As a matter of fact, the meaning and importance of the profession is still not understood by institutions and the public enough. For this reason, public relations are perceived as a field that manages media relations and organizes various organizations especially in terms of institutions. This perception prevents the institutionalization of public relations in the country, it also prevents them from becoming a management unit within the institution and playing a key role in corporate communication policies. Considering this situation of public relations in the country, there is much to be done both for the development of the field and professionalization of the job.

Based on the results of this study, some suggestions should be made to determine the basic role perceptions of public relations practitioners in Kyrgyzstan. In this sense, it is seen that public relations practitioners in Kyrgyzstan should focus more on executive roles. Because in today's world, practitioners need to develop public relations programs 
in a systematic way and monitor the developments in this area quite closely. Accordingly, both institutions, practitioners and public opinion should define and perceive public relations correctly. In most definitions made for public relations, it is emphasized that public relations is a management function. Therefore, public relations specialists are not the only the ones in the institution who do routine work; they are also a specialist who is in close relationship with the management, who develops public relations and communication programs, and conducts research and analysis. Specialists are required to improve their analytical and managerial skills to conduct comprehensive and efficient practices, and to establish all kinds of communicative policy together with their corporate managers. For this, it should be known and accepted by institutions that public relations is not a technical process for institutions; rather it is a vital management function.

\section{References}

Akar, H. (2011). Halkla İlişkiler Rolleri ve Algılanmasına Yönelik Uygulamalı Bir Çalışma (Doktora Tezi). Konya: Selçuk Üniversitesi Sosyal Bilimler Enstitüsü.

Artışeva, M. (2017). “Kırgızistan’da Halkla İlişkiler Mesleğinin Gelişmesinde Yüksek Öğretim Kurumlarının Rolü”. Manas Journal of Social Studies, 6(4), 541-558.

Berkowitz, D., \& Hristodoulakis, I. (1999). "Practitioners Roles, Public Relations Education, and Professional Socialization: An Exploratory Study". Journal of Public Relations Research, 11(1), 91-103.

Broom, G. (1986). "Public Relations Roles and Systems Theory: Functional and Historicist Causal Models". Annual Meeting of the Association for Education in Journalism and Mass Communication, pp.1-21.

Broom, G., \& Smith, G. (1978 August). "Toward an Understanding of Public Relations Roles: An Empirical Test of Five Roles: Models' Impact on Clients". Paper presented at the Annual Meeting of the Association for Education in Journalism, Seattle.

Culberston, H. (1985). "Public Relations Practitioner Roles - Their Meanings for Educators". Paper presented at the Annual Meeting of the Association for Education in Journalism and Mass Communication, Memphis.

Dey, I.(1993).Qualitative Data Analysis: A User Friendly Guide for Social Scientists. Routledge Publications.

Dozier, D. (1984). "Program evaluation roles of practitioners". Public Relations Review, 10(2), 13-21.

Holtzhausen, D., Petersen, B. \& Tindall, N. (2009). "Exploding in the Myth of the Symmetrical/Asymmetrical Dichotomy: Public Relations Models in the New South Africa". Journal of Public Relations Research, 15(4), 305-341. 
Johnson, M. (1997). "Public Relations and Technology: Practitioner Perspectives". Journal of Public Relations Research, 9(3), 213-236.

Karataş, Z. (2015). "Sosyal Bilimlerde Nitel Araştırma Yöntemleri”. Manevi Temelli Sosyal Hizmet Araştırmaları Dergisi, 1(1), 62-80. https://www.researchgate.net/publication/326572259_Sosyal_Bilim_Arastirmalarin da_Paradigma_Degisimi_Nitel_Yaklasimin_Yukselisi

Moss, D., Warnaby, G., \& Newman, A. J. (2000). "Public Relations Practitioners Role Enactment at the Senior Management Level Within U. K. Companies". Journal of Public Relations Research, 12(4):277-307.

Shulte, Y. (2008) Analusis of The Process of Democratization in Kyrgyzstan Trough The Definition of The Role and Functions of NGOs. Kyrgyzstan ant The Present Stage of Development. Bişkek: Center of Social Research, American University of Central Asia.

Şimşek, H., ve Yıldırım, A. (2005). Sosyal Bilimlerde Nitel Araştırma Yöntemleri: Seçkin Yayıncılık.

Steyn, B. \& Everett, T. (2009). "International Comparative Study Indicates Different PR Roles in South Africa and The UK, Using the Same Measuring Instrument". Tripodos 24 (2009), 95-105. https://www.academia.edu/6330643/2009_B_Steyn_and_T_Everett_International_c omparative_study_indicates_different_PR_roles_in_South_Africa_and_the_UK_us ing_the_same_measuring_instrument

Terry, V. (2009). "Lobbyists and Their Stories: Classic PR Practitioner Role Models as Functions of Burkean Human Motivations". Journal of Public Relations Research, 13, 235-263. doi: 10.1207/S1532754XJPRR1303_3

Toth, E.L., Serini, S.A.,Wright, D.K., \& Emig, A. (1998). "Trends In Public Relations Roles: 1990-1995”. Public Relations Review, 24(2), 145-163.

Vercic, D., van Ruler, B., ButschI, G., \& Flodin, B. (2001). "On the definition of public relations: a European view”. Public Relations Review 27, 373-387. Vzglyad. (2014). Public Relations Development Trends in Kyrgyzstan. https://vzglyad.kg/society/2132_presskafe_tendentsii_razvitiya_PR_v_kyirg yizstane_stenogramma/ 